\title{
ARTICLES
}

Submitted 08.12.2019. Approved 03.31.2021

Evaluated through a double-blind review process. Scientific Editor: Marcus Gomes

Original version | DOI: http://dx.doi.org/10.1590/So034-759020220102

\section{GREENHOUSE GAS EMISSION ALLOWANCES: FINANCIAL REPORTING TRANSPARENCY}

\author{
Licenças de emissão de gases com efeito de estufa: Transparência da informação financeira \\ Derechos de emisión de gases de efecto invernadero: Transparencia de la información financiera
}

Patricia Milanés-Montero'1 $^{1}$ pmilanes@unex.es | ORCID: 0000-0001-7328-5519

Esteban Pérez-Calderón ${ }^{1}$ | estperez@unex.es | ORCID: 00oo-0o02-4193-3769

Ana Isabel Dias² | aidias@iscal.ipl.pt | ORCID: 0000-0002-6503-4792

${ }^{1}$ University of Extremadura, Faculty of Economics and Businnes, Badajoz, Spain

${ }^{2}$ Lisbon Polytechnic Institute, Lisbon Accounting and Business School, Lisbon, Portugal

\begin{abstract}
This research analyzes the influence that the performance of GHG emissions has on the level of transparency in financial reporting. Content analysis of the financial statement notes allowed the level of transparency to be measured. The results suggest that the level of transparency in financial reporting is negatively related to the performance of GHG emissions when financial reports are prepared on the basis of the International Financial Reporting Standards. It was also concluded that more 'good news' is disclosed by companies when their GHG emissions' performance reduces. This study complements previous literature about transparency in financial reporting, and the necessity to relate it to eco-efficiency measures to empower the decision-making process of stakeholders. The study also provides a reference for European accounting regulators on the behavior of companies with regard to this issue.
\end{abstract}

KEYWORDS | Greenhouse gas emissions, International Financial Reporting Standards, financial reporting, panel data.

\section{RESUMO}

Este estudo analisa a influência do comportamento das emissões de gases de efeito estufa no nível de transparência da informação financeira. Uma análise de conteúdo dos anexos às contas anuais das empresas permitiu medir seu nível de transparência. Os resultados sugerem que o nível de transparência da informação financeira está negativamente relacionado com o desempenho das emissões de gases de efeito estufa quando elaborado com base nas normas internacionais de relatório financeiro. Além disso, concluiu-se que essas empresas revelam mais "boas notícias" quando há baixo desempenho nas emissões de gases. Este estudo complementa a literatura anterior sobre a transparência da informação financeira e a necessidade de relacioná-la com medidas de ecoeficiência para melhorar a tomada de decisões dos usuários da informação. 0 estudo constitui igualmente uma referência para os órgãos reguladores contábeis europeus sobre o comportamento das empresas nesse domínio.

PALAVRAS-CHAVE I Emissões de gases de efeito estufa, norma internacional de relatório financeiro, relatório financeiro, dados em painel.

\section{RESUMEN}

Esta investigación analiza la influencia que tiene el comportamiento de las emisiones de gases de efecto invernadero (GEI) en el nivel de transparencia de la información financiera. El análisis del contenido de las notas de los estados financieros de las compañías permitió medir el nivel de transparencia. Los resultados sugieren que el nivel de transparencia de la información financiera está negativamente relacionado con el desempeño de las emisiones de GEI cuando los informes financieros se preparan sobre la base de las Normas Internacionales de Información Financiera. Además, se llegó a la conclusión de que esas empresas revelan más "buenas noticias" cuando se reduce el rendimiento de las emisiones de gases. Este estudio complementa la literatura anterior sobre la transparencia de la información financiera y la necesidad de relacionarla con las medidas de ecoeficiencia para potenciar el proceso de toma de decisiones de los grupos de interés. Asimismo, el estudio proporciona una referencia para los reguladores contables europeos sobre el comportamiento de las empresas en esta materia.

PALABRAS CLAVE I Emisiones de gases de efecto invernadero, norma internacional de información financiera, información financiera, datos en panel. 


\section{INTRODUCTION}

Accounting environmental matters incorporates a two-fold type of information for stakeholders (Burritt, Schaltegger, \& Zvezdov, 2011): on the one hand, the financial impacts induced by environmental issues, and on the other, the physical impacts on the environment that sometimes result in a relationship of conflict and/or dependency.

Interest in the financial impacts of environmental matters has increased in the European Union (EU) following two milestones (Llena, Moneva, \& Hernandez, 2007): Recommendation 2001/453 of May 30 on the recognition, measurement and disclosure of environmental information in annual accounts and annual reports; and implementation of the European Union Emission Trading Scheme (EU ETS). Both of these indicate that environmental behavior should be published in company accounts and/or management reports, insofar as they may have an influence on the financial situation.

In the context of a cap-and-trade emissions trading scheme, the literature agrees that transactions should be included in financial reports (Giner-Inchausti, 2014; Lovell, Bebbington, Larrinaga, \& Aguiar, 2013 PricewaterhouseCoopers \& International Emissions Trading Association, 2007; Ragan \& Stagliano, 2007). The accounting treatment of emission allowances (EAs) and GHG emissions increased in importance with the development of regulated markets, such as the EU ETS, as they can have a significant economic and financial influence on financial statements, whether with regard to the nature of transactions, or in terms of value (Mateos \& Bilbao, 2007; Warwick \& Ng, 2012).

Despite the much-discussed materiality of EU ETS transactions, by incorporating an accounting treatment for their nature, companies are enabling fair and transparent comparisons to be made between financial statements (Giner-Inchausti, 2014), as non-disclosure may result in a distortion of the information that is disclosed (Ragan \& Staliano, 2007). This study argues that an eloquent aspect to consider in adopting accounting policies to include those transactions that reflect the companies' participation in the EU ETS should be transparency when disclosing these polices (Haupt \& Ismer, 2011), in the same way that financial reporting has achieved with other environmental matters (Larrinaga, Carrasco, Correa, Llena, \& Moneva, 2002; Ortas, Gallego-Álvarez, \& ÁlvarezEtxeberria, 2015).

Some regulators acknowledge that financial reports should incorporate information about transactions involving EAs and GHG emissions, which, from our point of view, would contribute towards increasing the levels of transparency of these reports.

Frequently discussed in the literature, but mainly with regard to voluntary reports, is the influence that environmental performance has on environmental disclosure (Cho \& Patten, 2007; Clarkson, Li, Richardson, \& Vasvari, 2008; Liu, Zhou, Yang, \& Hoepner, 2017; Milanés-Montero \& Pérez-Calderón, 2011; Patten, 2002). With the growing concern to include environmental matters in financial reporting, Larrinaga et al. (2002) and Llena et al. (2007) suggested that this is not just a response to mandatory regulation, but also to the motivation to project a less negative image to stakeholders. In relation with the EU ETS, this less negative image may be provided by measuring the performance of GHG emissions, which is suggested in this study as being an influence on the levels of transparency in the financial reporting of environmental matters. This research analyzes the influence that the GHG emissions' performance has on the level of transparency in financial reports when they are prepared on an International Financial Reporting Standards basis. The analysis is developed taking into consideration the level of information about good and bad news that is disclosed by companies depending on their GHG emissions' performance. Transparency in financial reporting is related to eco-efficiency measures given the importance of 
this information in the decision-making processes of stakeholders. The study distinguishes itself from previous studies because: (1) it addresses the importance of the level of transparency for EAs and GHG emissions in financial reporting; (2) it relates a measure of environmental financial reporting to a measure of environmental performance, which is a new approach to the relationship of items that are frequently associated in the literature.

\section{BACKGROUND AND HYPOTHESIS DEVELOPMENT}

\section{The financial reporting of EAs, GHG emissions and transparency issues}

In 2005 the IASB released IFRIC 3 'Emission Rights' for application after the beginning of Phase I of the EU ETS, but just six months later it decided to withdraw the interpretation, arguing that there had been a misinterpretation of the urgency of the standard. The justification for doing so, which was in line with negative advice coming from the European Financial Reporting Advisory Group (EFRAG), was that the prescribed accounting treatment created mismatches in financial statements. EFRAG and extensive previous literature (Bebbington \& LarrinagaGonzález, 2008; Black, 2013; Ertimur, Francis, Gonzales \& Schipper, 2017; Giner-Inchausti, 2014; Lovell et al., 2013; MacKenzie, 2009; Steenkamp, Rahman, \& Kashyap, 2011; Veith, Zimmermann, \& Werner, 2009; Warwick \& Ng, 2012) had pointed out that the mismatches introduced by IFRIC 3 were mainly due to a discordant measurement of the assets (the EAs) and the liabilities (GHG emissions), because the EAs were measured at cost, or a revaluation amount, while the liability was at fair value, which would result in an artificial volatility in the reported earnings and would not reflect the economic reality of the companies.

The withdrawal of IFRIC 3 was the start of an absence of international accounting regulations, with consequences as to the use of multiple accounting practices, as pointed out in various descriptive empirical studies (Ayaz, 2017; Black, 2013; Lovell, Aguiar, Bebbington, \& Larrinaga-Gonzales, 2010; PWC \& IETA, 2007; Warwick \& Ng, 2012). Notwithstanding the IASB's position, national regulatory authorities felt impelled to overcome the lack of guidance (Cuesta, Moneva, \& Larrinaga, 2006).

Previous literature has also concluded that there was highly frequent non-disclosure (Black, 2013; Lovell et al., 2010; PWC \& IETA, 2007; Warwick \& Ng, 2012). This may have been due to professional judgement interpreting transactions in a market that is based on the cap-and-trade system as being materially relevant (Busch \& Hoffman, 2001). This is due to the grandfathering system that is considered in Phases I, II and even Phase III of the EU ETS for allocating EAs. This system also frequently justifies the adoption of off-balance sheet policies (Criado-Jiménez, Fernández-Chulián, Husillos-Carqués, \& Larrinaga-González, 2008), although Lovell et al. (2013), providing evidence of the significant materiality of EAs, undermine the grounds of this justification.

Although there is a certain skepticism with regard to the usefulness of imposing recognition of these transactions (Giner-Inchausti, 2007), the multitude of approaches, including the use of off-balance sheet policies and non-disclosure, underlines the importance of having a common accounting treatment for obtaining transparency when comparing the financial reporting of EAs and GHG emissions (Giner-Inchausti, 2014; Lovell et al., 2010). In this respect we stress that the qualitative characteristic of relevance is not limited to materiality. It includes nature relevance, which is useful when revealing key disclosures, mainly in relation to environmental matters. Moreover, although transparency is not a principle established in the Conceptual Frameworks, Barth and Schipper (2008) include this perspective in their concept of financial reporting transparency. 
With regard to company behavior in the financial disclosure of environmental matters, Llena et al. (2007) concluded that companies disclose less 'bad news', like provisions and contingencies, than 'good news', such as investments and expenses. In a context of a multitude of approaches, therefore, achieving a higher level of transparency for EAs that are received for free, or for the liability with regard to GHG emissions, may not require mandatory reporting, as it may be connected with a company's motivation to disclose its attitude to the EU ETS (Adams, Coutts, \& Harte, 1995). We therefore question whether the level of transparency in financial reporting that is imposed by national accounting standards, with a specific mandatory treatment, is significantly different from the level that is based on the IFRS, although the latter is recognized as a higher-quality set of financial standards.

Based on the Wiseman index, which focuses on the financial consequences of environmental activities, Clarkson et al. (2008) concluded that when exposure to GHG emission controls increases, mandatory disclosures in annual reports and $10 \mathrm{~K}$ forms also increase. In fact, under voluntary disclosure schemes, the relationship between a company's environmental disclosure and its environmental performance has been frequently tested, but to our knowledge there are fewer studies into financial reporting. The next section develops the arguments on the influence of the GHG emissions' performance on the level of transparency in financial reporting, which will serve as the basis for formulating our hypothesis.

\section{The influence of the performance of GHG emissions on the level of transparency in financial reporting}

The EU ETS is a market-based mechanism aimed at controlling GHG emissions and making the costs of these emissions visible, and this has been a controversial issue, particularly in financial reporting, as discussed in the previous section. Financial reporting is a way of revealing to stakeholders the regulatory and market risks that influence accounting-based measures of performance (Schiemann \& Sakhel, 2019).

In current literature, the level of transparency in financial reporting is frequently related to external factors that are imposed on companies, such as reporting regulations (Gallego-Álvarez, Martínez-Ferrero, \& CuadradoBallesteros, 2016; Giner-Inchausti, 1997; Veith et al., 2009), or to company characteristics, such as their environmental performance under the EU ETS. Jaggi, Allini, Macchioni and Zagaria (2018) state that it is important for investors to evaluate company risks that are associated with their carbon performance, which underlines the importance of greater transparency in carbon disclosures, even in code law countries. Conceptual frameworks for financial reporting, which define the fundamental concepts of the IFRS, state that financial disclosure has to be useful for stakeholders. This is the basis for arguing that there should be some correspondence between useful information and the performance measures of GHG emissions, with the advantage of obtaining (observable) fair value, which the market mechanism attributes to both EAs and GHG emissions (Ascui \& Lovell, 2012). Lovell et al. (2013) also provided evidence that the materiality of EAs ranges from $14 \%$ to $85 \%$ of the profit/loss before tax, although they recognized that there is no obvious calculation for carbon accounting.

The disclosed accounting policies identified in the literature (Black, 2013; Lovell et al., 2010; Warwick \& $\mathrm{Ng}, 2012$ ) can be aggregated into two perspectives (Larrinaga et al., 2002): on one hand, companies may neglect aspects of the regulation that are not in their interests to report, and adopt a strategy of concealment (CriadoJiménez et al., 2008) by using non-disclosure or off-balance sheet policies; and on the other, companies with better performance measures have a motivation to disclose more information, basing on approaches that provide related information, thereby improving their transparency. 
Previous literature has concluded that, in general, there is no significant association between environmental disclosure and environmental performance (Al-Tuwaijri, Christensen, \& Hughes, 2004), although authors such as Qian \& Schaltegger (2017) have found that a change in the level of carbon disclosure motivates an improvement in carbon performance. Although it was not a causal study, and we cannot relate it 'the other way around', we question if there is new evidence of improved levels of transparency motivated by behaviors with regard to GHG emissions. Based on the review of previous studies, we expect a lack of visibility in the performance of GHG emissions with respect to its level of transparency. Thus, we formulate the following non-directional hypothesis:

$\mathrm{H}_{1}$ : The level of transparency of the financial reporting of EAs and GHG emissions is not influenced by the performance of GHG emissions.

The following section presents our empirical research design and the methodology used for testing the hypothesis we formulated.

\section{METHODOLOGY}

\section{Sample and data}

As primary sources, we used national allocation plans (NAPs), annual financial statements and the European Commission's website in connection with the documentation of the Union Registry. Portugal, Spain and France were chosen because our focus is on distinguishing the effect of GHG emissions' performance on the level of transparency of financial reporting that is based on national accounting standards, which have an explicit accounting treatment for EAs and GHG emissions, from the full IFRS guidelines, which have no specific guidance in this respect. In all three countries listed companies must use IFRS when preparing and reporting their consolidated accounts.

The study period runs from 2008 to 2014, i.e., all five years of Phase II and the first two years of Phase III. It was not possible to compile the annual financial statements for the seven years for 88 companies, but initially we obtained 559 observations, an unbalanced panel.

In this study content analysis of the year-end financial statements was used to evaluate the accounting policies adopted in relation to the treatment of EAs and GHG emissions (Ayaz, 2017; Black, 2013; Steenkamp et al., 2011; Warwick \& Ng, 2012) as annual accounts are the primary source of information employed by accounting practices.

Content analysis has become one of the commonest forms of data analysis used for providing descriptive knowledge and understanding a particular phenomenon being studied. It is often criticized, however, for its lack of rigor, the limited utility of its findings (Doris, Leung, Betty, \& Chung, 2019), and for being an overly simple method. This may be the reason why this analysis process has been little discussed in literature. Unexpected difficulties may arise during the analysis process, however because: authors often see the beginning of the categorization phase as chaotic, since at that point they possess several, seemingly unconnected pieces of information; narrative material is generally not linear; and paragraphs from transcribed interviews may contain elements relating to several categories. To resolve this situation, it is necessary to be prepared to go back to the data to check the reliability of the categories (Elo \& Kyngas, 2008).

In this research, using this analysis technique we were able to assess individual accounting policies for recognizing and measuring EAs and GHG emissions as disaggregated, since it was believed that this would answer 
some fundamental questions. These accounting policies are summarized by Elfrink and Ellison (2009) and EFRAG $(2012,2013)$ as those that, until now, have been discussed by academics, European national regulators and companies that are active participants in the EU ETS. Without this extensive analysis of the content of the Notes presented in the complete set of financial statements, an appropriate level of transparency could not have been achieved.

Information on GHG emissions was obtained from the website of the Union Registry, the most reliable source of data on allocated and verified GHG emissions (Yu, 2013). The report, Verified Emissions for 2014, was used to identify the historical data for each operator/year since 2008 , which we added to the respective company/ year in accordance with the practices in literature (Ertimur et al., 2017). The final composition of the sample is an unbalanced panel of 85 companies: 540 observations, 352 for IFRS-based financial reporting, and 188 for reporting based on national standards.

\section{Variables}

The disclosure indices (IDS) are self-constructed, based on the content analysis of annual financial statements; GHG emissions were retrieved from the Verified Emissions Report for 2014, and financial and economic data were taken from annual financial statements and/or the Amadeus database. Exhibit 1 describes the variables, their respective measurements and the sources.

\section{Dependent variables}

To measure the level of transparency of the financial reporting of EAs and GHG emissions, the indices constructed are frequently used to reflect on aspects related to environmental activities (Liu et al., 2017; Matsumura, Prakash, \& Vera-Muñoz, 2014; Patten, 2002; Steenkamp et al., 2011).

Disclosure indices are the sum of the answers to the questions posed in the literature review, supported by the accounting policies prescribed by national regulators in Portugal, Spain and France (Black, 2013; Lovell et al., 2010; Warwick \& Ng, 2012). For this work, content analysis of the Notes was fundamental, as it allowed us to identify individual accounting policies for EAs and GHG emissions, which we compiled in eight items of recognition and measurement: I Initial recognition of assigned EAs; I2 Counterpart of initial recognition of assigned EAs; 13 Initial measurement of EAs; 14 Subsequent measurement of EAs; 15 Recognition of GHG emissions; 16 Measurement of GHG emissions; I7 Recognition of over-allocated GHG emissions; and I8 Acknowledgement of EAs acquired to cover GHG emissions over the cap. Each of these eight items was transformed into a dummy variable that takes the value 1 if any categorical information was disclosed, and o in cases of non-disclosure, or the disclosure of off-balance sheet policies. These last categories are assumed to be a way of reducing the levels of transparency in the financial reporting of EAs and GHG emissions. The ID is the sum of the eight dummy variables (I1 to I8), and a variable that takes the value $o$ if no accounting policy was disclosed, and the value 8 if all were identified in the Notes.

In order to distinguish the level of transparency between IFRS and national GAAPs (general accounting plans), two further indices were formulated: ID.IFRS that takes the value o if none of the eight items were disclosed on the IFRS basis, and 8 if all of them were; and ID.NGAAP that takes the value $o$ if none of the eight items were disclosed using national GAAPs, and 8 if all of them were. 
Exhibit 1. Variable definitions

\begin{tabular}{|c|c|c|c|c|}
\hline Variable & Type & Description & Measurement & Source \\
\hline$I D$ & \multirow{3}{*}{$\begin{array}{l}\text { Dependent variable } \\
\text { (Level of Transparency) }\end{array}$} & Disclosure index & \multirow{3}{*}{$\begin{array}{l}\text { Takes values from o to } 8 \\
\text { (is the sum of dummy } \\
\text { variables } 11 \text { to I8) }\end{array}$} & \multirow{9}{*}{$\begin{array}{l}\text { Notes } \\
\text { (Annual Financial } \\
\text { Statements) }\end{array}$} \\
\hline ID.IFRS & & $\begin{array}{l}\text { Disclosure index on an } \\
\text { IFRS basis }\end{array}$ & & \\
\hline ID.NGAAP & & $\begin{array}{l}\text { Disclosure index on a } \\
\text { national GAAP basis }\end{array}$ & & \\
\hline ID.EA & \multirow{6}{*}{$\begin{array}{l}\text { Dependent variable } \\
\text { (Level of Transparency } \\
\text { - Good news vs Bad } \\
\text { news) }\end{array}$} & $\begin{array}{l}\text { Disclosure index of } \\
\text { good news }\end{array}$ & \multirow{6}{*}{$\begin{array}{l}\text { Takes the values from } \\
\text { o to } 4 \\
\text { (is the sum of } 11 \text { to } 14 \text { for } \\
\text { EAs, or I } 5 \text { to } 18 \text { for } \mathrm{GHG} \\
\text { emissions) }\end{array}$} & \\
\hline ID.eGHG & & $\begin{array}{l}\text { Disclosure index of bad } \\
\text { news }\end{array}$ & & \\
\hline ID.IFRS.EA & & $\begin{array}{l}\text { Disclosure index of } \\
\text { good news in the IFRS }\end{array}$ & & \\
\hline ID.IFRS.eGHG & & $\begin{array}{l}\text { Disclosure index of bad } \\
\text { news in the IFRS }\end{array}$ & & \\
\hline ID.NGAAP.EA & & $\begin{array}{l}\text { Disclosure index of } \\
\text { good news in national } \\
\text { GAAP }\end{array}$ & & \\
\hline ID.NGAAP.eGHG & & $\begin{array}{l}\text { Disclosure index of bad } \\
\text { news in national GAAP }\end{array}$ & & \\
\hline GHGeP & Explanatory variable & $\begin{array}{l}\text { GHG emissions' } \\
\text { performance }\end{array}$ & $\begin{array}{l}\text { Ratio Net Sales to GHG } \\
\text { emissions (in } € \text { by } \\
\text { metric ton) }\end{array}$ & $\begin{array}{l}\text { Annual Financial } \\
\text { Statements / Amadeus } \\
\text { database + Verified } \\
\text { Emissions Report for } \\
2014\end{array}$ \\
\hline Size & \multirow{7}{*}{ Control variables } & Size of the company & $\begin{array}{l}\text { Logarithm of total } \\
\text { assets (in } € \text { ) }\end{array}$ & \multirow{6}{*}{$\begin{array}{l}\text { Annual Financial } \\
\text { Statements / Amadeus } \\
\text { database }\end{array}$} \\
\hline$R O A$ & & Return on Assets & $\begin{array}{l}\text { Ratio EBIT to Total } \\
\text { Assets (in } € \text { ) }\end{array}$ & \\
\hline$R O E$ & & Return on Equity & $\begin{array}{l}\text { Ratio Net Income to } \\
\text { Owners' Equity (in } € \text { ) }\end{array}$ & \\
\hline ROS & & Return on Sales & $\begin{array}{l}\text { Ratio net Sales to Total } \\
\text { Assets (in } € \text { ) }\end{array}$ & \\
\hline DebtE & & Debt to Equity ratio & $\begin{array}{l}\text { Ratio Total Debt to } \\
\text { Owners' Equity (in €) }\end{array}$ & \\
\hline DebtTA & & Debt to Assets ratio & $\begin{array}{l}\text { Ratio Total Debt to Total } \\
\text { Assets (in } € \text { ) }\end{array}$ & \\
\hline Audit & & $\begin{array}{l}\text { Presence of auditor's } \\
\text { report in annual } \\
\text { financial statements }\end{array}$ & $\begin{array}{l}\text { Dummy variable: takes } \\
\text { the value } 1 \text { if the annual } \\
\text { accounts contain an } \\
\text { auditor's report, and o } \\
\text { otherwise }\end{array}$ & $\begin{array}{l}\text { Annual Financial } \\
\text { Statements }\end{array}$ \\
\hline
\end{tabular}


The level of transparency of EAs and GHG emissions is also assessed by way of 'good news' and 'bad news': ID.EA related to EAs ( 11 to I 14 ) is seen as 'good news'; and ID.eGHG related to GHG emissions (I5 to I8) is seen as 'bad news'. Another four new dependent variables were generated in order to differentiate the levels of transparency of 'good news' and 'bad news' with regard to each financial reporting basis - IFRS and national GAAP: ID.IFRS.EA, ID.IFRS.eGHG, ID.NGAAP.EA, ID.NGAAP.eGHG, take the value 0 if none of the four items were disclosed, and 4 if all of them were.

\section{Independent variables: Treatment and control variables}

The ratio between net sales and GHG emissions (value of sales for each unit of GHG emissions) was used as a measure of the performance of GHG emissions. Ehrenfeld (2005) calls it a measure of eco-efficiency because it is the ratio of an economic value added to an environmental impact measure. Previous literature (Busch \& Hoffman, 2011; Clarkson, Li, Pinnuck, \& Richardson, 2015; Qian \& Schaltegger, 2017) uses carbon intensity, the inverted ratio of GHG emissions' performance (GHG emissions to economic value added), which is recognized as an eco-intensity measure (Ehrenfeld, 2005). The GHG emissions' performance ratio was transformed into a logarithm to avoid skewed parameters in accordance with previous literature (Busch \& Hoffman, 2011)

With regard to control variables, we expect that size, profitability, financial risk and external supervision are good for controlling the level of transparency, since they represent the characteristics of the company that are often used as an explanatory factor of disclosure (Gallego-Álvarez et al., 2016; Giner-Inchausti, 1997; Veith et al., 2009).

Company size is considered to be a positive influence on the disclosure of information, since it emphasizes that large firms are politically more sensitive and face pressures that smaller entities do not. Clarkson et al. (2008), Prado-Lorenzo, Rodríguez-Domínguez, Gallego-Álvarez and García-Sánchez (2009), Matsumura et al. (2014), Luo, Lang and Tang (2012) conclude that large companies disclose more information related to their GHG emissions. There are several measures to proxy size and we chose the logarithm of total assets, as did Giner-Inchausti (1997) and Gallego-Álvarez et al. (2016).

Profitability measures were often used by previous literature, because companies that perform better can be more transparent about their internal activities, and so profitable entities are expected to present more disclosures to justify their good performance (Roberts, 1992). Several studies simultaneously use return on assets (ROA) and return on equity (ROE) to control for profitability, as ROA reflects operating performance and ROE financial performance (Giner-Inchausti, 1997; Prado-Lorenzo et al., 2009; Qiu, Shaukat, \& Tharyan, 2016). Return on sales (ROS) was used because it represents a short-term return (Liu et al., 2017).

Leverage ratios are used to inform about default risks that may lead to investment and financing being avoided. They are often used as a covenant, which encourages managers to adopt accounting policies that avoid an inconvenient outcome (Connors \& Gao, 2011; Prado-Lorenzo et al., 2009). Several other measures are also used in the literature, two of which were included in this study: the ratio of debt to equity (Gallego-Álvarez et al., 2016; Ortas et al., 2015; Prado-Lorenzo et al., 2009), and the ratio of debt to assets (Busch \& Hoffman, 2011; Luo et al., 2012).

A report by an independent auditor certifies the reliability and relevance of accounting practices related to EAs and GHG emissions, thus lending greater credibility to the financial statements (Dechow, Ge, \& Schrand, 2010). The presentation of an external auditor's report is expected to have a positive impact on levels of transparency. 
The Audit variable is a dichotomous variable that takes the value 1 if the annual report incorporates the auditor's report, and o if it does not.

\section{Model and econometric analysis}

Our econometric model is different from previous literature in that it tries to assess what drives a company to disclose more financial information on exposure to EU ETS transactions. While we cannot directly represent the company's unobservable strategy, we can estimate the following relationship:

LevelTransparency ${ }_{\text {it }}=\int(G H G \text { emissions performance, } \text { control variables })_{\text {it }}$

Equation 1 was designed to verify the influence of GHG emissions' performance on the level of transparency of financial reporting.

$\mathrm{LT}_{\mathrm{it}}=\beta_{\mathrm{o}}+\beta_{1} \mathrm{NT} \mathrm{T}_{\mathrm{it}-1}+\beta_{2} \mathrm{GEEeD}_{\mathrm{it}}+\varnothing \mathrm{X}_{\mathrm{it}}+\varepsilon_{\mathrm{it}}$

Where:

- $\mathrm{i}$ and $\mathrm{t}$ are respectively company and year;

- LT represents the measures for the level of transparency: ID, ID.IFRS, ID.NGAAP, ID.EA, ID.eGHG, ID.IFRS. EA, ID.IFRS.eGHG, ID.NGAAP.EA, ID.NGAAP.eGHG;

- GHGeP is the logarithm of the ratio of net sales to GHG emissions;

- X corresponds to the control variables: Size is the logarithm of total assets; Profitability: ROA, ROE and ROS; Leverage: debt-to-equity ratio and debt-to-total assets ratio; Audit is a dummy variable for the presence of an independent auditor's report;

$-\varepsilon$ is the error term.

To test Equation 1, we employed a regression technique using panel data, which enables us to assess the transparency of the financial reporting over the periods, by analyzing observations from several consecutive years for the same sample companies. Dynamic models have two main advantages (Pindado \& Requejo, 2015): they control for unobserved heterogeneity, i.e., individual effects, such as the management's professional judgement about financial reporting, the levels of transparency in the reports, or awareness of GHG emissions; and they help mitigate the endogeneity problem that occurs when the error term is correlated with any of the instrumental variables. The estimator chosen was the Generalized Method of Moments (GMM) system, according to the model developed by Arellano and Bover (1995) that has been applied in previous literature (Abrell , Ndoye, Zachmann, 2011; Yu, 2013). Despite the scarce literature on the relationship in question, we are conscious of the causal relationships in the proposed model. In this sense, endogeneity was addressed by using instrumental variables, which are more commonly expressed as delays of the endogenous variables (Labra \& Torrecillas, 2014). As usual in GMM literature, we introduced the first lag of the dependent variable as a regressor, and the lags of the explanatory and control variables as instruments. These lagged values are natural candidates for valid instruments because we can prove them to be uncorrelated with the error term when deriving the estimator. They also contain information on the current value of the variable as there is frequently a delay between the decision made by individuals and its actual realization (Labra \& Torrecillas, 2014). Arellano and Bond (1991) argue that using more instruments is 
a way of increasing efficiency, which Pindado and Requejo (2014) conclude to be an adequate strategy for short periods of time. Explanatory and control variables are considered to be endogenous variables. In order to control the heteroscedasticity of the panels we included the robustness option to determine the standard deviation in the model, as suggested by Windjmeier (2005).

\section{RESULTS}

Summary statistics are evidence that the level of transparency increased in the case of national GAAPs and decreased for the IFRS basis (see Table 1).

Table 1. Summary statistics and correlation matrix

\begin{tabular}{|c|c|c|c|c|c|}
\hline Variable & Obs. & Mean & Std. Dev. & Min. & Max. \\
\hline$I D$ & 540 & 5,0037 & 2,8875 & o & 8 \\
\hline ID.IFRS & 352 & 4,7585 & 3,0450 & 0 & 8 \\
\hline ID.NGAAP & 188 & 5,4628 & 2,5107 & 0 & 8 \\
\hline ID.EA & 540 & 2,8000 & 1,6268 & 0 & 4 \\
\hline ID.eGHG & 540 & 2,2037 & 1,4682 & o & 4 \\
\hline ID.IFRS.EA & 352 & 2,6392 & 1,7040 & o & 4 \\
\hline ID.IFRS.eGHG & 352 & 2,1193 & 1,5238 & 0 & 4 \\
\hline ID.NGAAP.EA & 188 & 3,1011 & 1,4275 & 0 & 4 \\
\hline ID.NGAAP.eGHG & 188 & 2,3617 & 1,3472 & 0 & 4 \\
\hline GHGeP & 540 & 7,4819 & 2,1174 & 3,1761 & 14,4616 \\
\hline Size & 540 & 19,5453 & 1,9484 & 14,4998 & 24,5375 \\
\hline$R O A$ & 540 & 0,0517 & 0,1197 & $-1,2022$ & 0,5791 \\
\hline$R O E$ & 540 & 0,1021 & 0,3392 & $-2,8407$ & 4,0087 \\
\hline ROS & 540 & 0,8227 & 0,5136 & 0,0082 & 3,0855 \\
\hline DebtE & 540 & 1,7876 & 3,2518 & $-28,0376$ & 33,1463 \\
\hline DebtA & 540 & 0,5549 & 0,2765 & $-1,1387$ & 1,5476 \\
\hline Audit & 540 & 0,8407 & 0,3663 & 0 & 1 \\
\hline
\end{tabular}


The correlation matrix shows that a higher measure of GHG emissions' performance is negatively associated with levels of transparency, although the coefficient indicates that the reduction is not significant, as we expected because of the materiality issues mentioned above (See Table 2 ).

Table 2. Spearman's correlation matrix

\begin{tabular}{|c|c|c|c|c|c|c|c|c|c|c|c|c|c|c|c|c|c|}
\hline & 1) & 2) & 3) & 4) & 5) & 6) & 7) & 8) & 9) & 10) & 11) & 12) & 13) & 14) & 15) & 16) & 17) \\
\hline $\begin{array}{l}\text { 1) } \\
\mathrm{IE}\end{array}$ & 1 & & & & & & & & & & & & & & & & \\
\hline $\begin{array}{c}\text { 2) } \\
\text { ID.IFRS }\end{array}$ & $0.8417^{*}$ & 1 & & & & & & & & & & & & & & & \\
\hline $\begin{array}{c}\text { 3) } \\
\text { ID.NGAAP }\end{array}$ & $0.9526^{*}$ & $0.6839^{\star}$ & 1 & & & & & & & & & & & & & & \\
\hline $\begin{array}{c}\text { 4) } \\
\text { ID.EA }\end{array}$ & 10.000 & $0.9056^{*}$ & $0.9608^{*}$ & 1 & & & & & & & & & & & & & \\
\hline $\begin{array}{c}\text { 5) } \\
\text { ID.eGHG }\end{array}$ & $0.9056^{*}$ & $1.0000^{*}$ & $0.7923^{*}$ & $0.9056^{*}$ & 1 & & & & & & & & & & & & \\
\hline $\begin{array}{c}6) \\
\text { ID.IFRS.EA }\end{array}$ & $0.9608^{*}$ & $0.7923^{*}$ & $1.0000^{*}$ & $0.9608^{\star}$ & $0.7923^{\star}$ & 1 & & & & & & & & & & & \\
\hline $\begin{array}{c}\text { 7) } \\
\text { ID.IFRS. } \\
\text { eGHG }\end{array}$ & 10.000 & $0.6121^{*}$ & $0.9440^{*}$ & -- & -- & -- & 1 & & & & & & & & & & \\
\hline $\begin{array}{c}8) \\
\text { ID.NGAAP. } \\
\text { EA }\end{array}$ & $0.6121^{*}$ & $1.0000^{*}$ & $0.3698^{*}$ & -- & -- & -. & $0.6121^{\star}$ & 1 & & & & & & & & & \\
\hline $\begin{array}{c}\text { 9) } \\
\text { ID.NGAAP. } \\
\text { eGHG }\end{array}$ & $0.9440^{*}$ & $0.3698^{\star}$ & $1.0000^{*}$ & -- & -- & $-\cdot$ & $0.9440^{*}$ & $0.3698^{*}$ & 1 & & & & & & & & \\
\hline $\begin{array}{l}\text { 10) } \\
\text { GHGeP }\end{array}$ & $-0.1940^{*}$ & $-0.1135^{*}$ & $-0.2089^{*}$ & $-0.1998^{*}$ & $-0.1202^{\star *}$ & $-0.2179^{*}$ & $-0.2524^{*}$ & -0.1058 & $-0.2200^{*}$ & 1 & & & & & & & \\
\hline $\begin{array}{l}\text { 11) } \\
\text { Size }\end{array}$ & -0.0367 & -0.0589 & -0.0221 & 0.0213 & 0.0717 & -0.0002 & $-0.2123^{*}$ & $-0.2931^{\star}$ & -0.1130 & $-0.1744^{\star}$ & 1 & & & & & & \\
\hline $\begin{array}{l}\text { 12) } \\
\text { ROA }\end{array}$ & $0.1671^{\star}$ & $0.104^{\star *}$ & $0.1728^{\star}$ & $0.2560^{\star}$ & $0.2004^{*}$ & $0.2701^{\star}$ & 0.0049 & $-0.1222^{\star \star \star}$ & * -0.0054 & $0.3658^{*}$ & -0.0704 & 1 & & & & & \\
\hline $\begin{array}{l}\text { 13) } \\
\text { ROE }\end{array}$ & $0.1098^{* *}$ & 0.0228 & $0.1300^{*}$ & $0.1663^{\star}$ & $0.1186^{\star \star}$ & $0.1730^{*}$ & 0.0060 & $-0.2067^{\star}$ & 0.0536 & $0.2240^{*}$ & -0.0444 & $0.6963^{*}$ & 1 & & & & \\
\hline $\begin{array}{l}\text { 14) } \\
\text { ROS }\end{array}$ & $0.1427^{*}$ & $0.1482^{*}$ & $0.1390^{*}$ & $0.1918^{*}$ & $0.1901^{*}$ & $0.1787^{\star}$ & 0.0069 & -0.0222 & 0.0466 & $\mid-0.0602$ & $-0.2407^{\star}$ & $0.1111^{\star}$ & -0.0074 & 1 & & & \\
\hline $\begin{array}{c}\text { 15) } \\
\text { DebtE }\end{array}$ & -0.0268 & $-0.1252^{*}$ & 0.0218 & -0.0049 & $-0.0898^{\star}$ & 0.0127 & -0.1104 & $-0.1970^{\star}$ & 0.0180 & $-0.0815^{\star \star \star}$ & $0.0963^{\star *}$ & $-0.1296^{*}$ & 0.0185 & $-0.1259^{\star}$ & 1 & & \\
\hline $\begin{array}{c}\text { 16) } \\
\text { DebtA }\end{array}$ & $-0.1036^{* *}$ & $-0.2050^{*}$ & -0.0502 & $-0.1323^{\star \star}$ & $-0.2189^{\star}$ & $-0.1105^{\star \star}$ & -0.0762 & $-0.1722^{\star \star}$ & 0.0541 & $-0.1319^{*}$ & $0.1111^{\star}$ & $-0.1963^{\star}$ & 0.0519 & $-0.1111^{\star}$ & $0.8889^{\star}$ & 1 & \\
\hline $\begin{array}{l}\text { 17) } \\
\text { Audit }\end{array}$ & $0.1102^{\star \star}$ & 0.0613 & $0.1489^{\star}$ & -0.0383 & 0.0174 & -0.0262 & $0.4243^{*}$ & $0.1715^{\star \star}$ & $0.4783^{\star}$ & $0.1389^{\star}$ & $0.0859^{\star \star}$ & $0.0859^{\star \star}$ & -0.0573 & $-0.1718^{\star}$ & $0.1074^{\star *}$ & -0.0644 & 1 \\
\hline
\end{tabular}


The correlation is higher for levels of disclosure based on national standards, although the index of 'good' news is not statistically significant. Size is negatively correlated with levels of transparency, excluding those based on IFRS, but only significant when national GAAPs are applied. The profitability variables are positively correlated with the levels of transparency in IFRS, and negatively correlated with the level of transparency for 'good' news in national GAAPs. Leverage ratios present negative statistically significant correlations with the level of transparency of EAs, in both IFRS and national GAAPs. Having an auditor's report is positively correlated with the levels of transparency in national GAAPs, and is stronger for the transparency of 'bad' news. The performance of GHG emissions is positively correlated with ROA, ROE and an auditor's report, and negatively correlated with size and leverage (see Table 2).

Tables 2 to 4 show the results for Equation 1. We would point out that adopting off-balance sheet policies was considered equivalent to nondisclosure, as they reduce the level of transparency in the financial report. The total number of observations reduces because of the introduction into the model of the dependent variable with the delay of a period as an explanatory variable.

There is no evidence in the model specification tests of first and second order autocorrelation in the errors of the first difference ( $\mathrm{m}_{1}$ and $\mathrm{m} 2$ ), but model 3 in Table 4 is cause for concern as the $\mathrm{p}$-value is at the $10 \%$ level. Hansen tests suggest that the instruments are valid, but in Table 6 models 1 and 2 show signs of over-identification, as the p-values of Hansen are 0,734 and 0,803, respectively. The number of instruments used is high for the number of observations, but as it does not exceed the number of groups the models remain valid, although it is weaker. Wald tests provide acceptable results for the joint significance of the explanatory variables, but not efficient results for the control variables. Time dummies are not jointly significant, as we expected considering the consistency necessary in accounting policies in order to achieve comparability.

Table 3 suggests that the effect of the GHG emissions' performance on the transparency level of financial reporting is negative and statistically significant, i.e., companies disclose fewer accounting policies with regard to GHG emissions when the performance of their emissions improves.

\section{Table 3. Results for the level of transparency - IFRS and national GAAP}

\begin{tabular}{|c|c|c|c|c|c|c|}
\hline & \multicolumn{2}{|l|}{ (1) ID } & \multicolumn{2}{|l|}{ (2) ID.EA } & \multicolumn{2}{|l|}{ (3) ID.eGHG } \\
\hline & Coef. & Std. Er. & Coef. & Std. Er. & Coef. & Std. Er. \\
\hline DepVar t-1 & $0.2655^{\star *}$ & 0.1043 & $0.3003^{\star}$ & 0.0883 & $0.3123^{\star \star \star}$ & 0.1708 \\
\hline GHGeP & $-0.3643^{* \star *}$ & 0.2059 & -0.0858 & 0.0982 & $-0.2263^{* \star *}$ & 0.1334 \\
\hline Size & 0.6457 & 0.5301 & $0.4704^{\star \star}$ & 0.2029 & 0.1942 & 0.3439 \\
\hline ROA & 0.0791 & 0.1762 & 0.0404 & 0.0962 & 0.0423 & 0.0839 \\
\hline ROE & -0.2126 & 0.1484 & -0.1297 & 0.0832 & -0.0311 & 0.0893 \\
\hline ROS & $0.5016^{\star \star \star}$ & 0.2589 & 0.2062 & 0.1474 & 0.1292 & 0.1574 \\
\hline DebtE & 0.3523 & 0.3266 & 0.2648 & 0.2040 & 0.1902 & 0.1670 \\
\hline DebtA & -0.2685 & 0.3834 & -0.1793 & 0.2540 & -0.1487 & 0.2081 \\
\hline Audit & $2.7846^{\star \star}$ & 1.3441 & $1.6633^{\star \star}$ & 0.6688 & 0.8996 & 0.7069 \\
\hline _cons & 2.0628 & 1.4832 & -- & -- & $1.7351^{\star \star \star}$ & 0.9506 \\
\hline i.Year & Yes(1) & & Yes(1) & & Yes(1) & \\
\hline
\end{tabular}


Table 3. Results for the level of transparency - IFRS and national GAAP

\begin{tabular}{|c|c|c|c|c|c|c|}
\hline & \multicolumn{2}{|l|}{ (1) ID } & \multicolumn{2}{|l|}{ (2) ID.EA } & \multicolumn{2}{|c|}{ (3) ID.eGHG } \\
\hline & Coef. & Std. Er. & Coef. & Std. Er. & Coef. & Std. Er. \\
\hline $\begin{array}{l}\text { N.obs / } \\
\text { N.groups }\end{array}$ & $453 / 85$ & & $453 / 85$ & & $453 / 85$ & \\
\hline $\mathrm{N}$ instruments & 56 & & 56 & & 54 & \\
\hline F statistic & $4 \cdot 19^{\star}$ & & $90.05^{*}$ & & $2.14^{\star}$ & \\
\hline m1 & 0.034 & & 0.018 & & 0.036 & \\
\hline m2 & 0.882 & & 0.507 & & 0.236 & \\
\hline $\begin{array}{l}\text { Hansen J } \\
\text { statistic }\end{array}$ & \multicolumn{2}{|c|}{$\begin{array}{l}\operatorname{chi} 2(39)=43.48 \\
\text { Prob }>\text { chi2 }=0.286\end{array}$} & \multicolumn{2}{|c|}{$\begin{array}{l}\operatorname{chi} 2(39)=42.56 \\
\text { Prob }>\text { chi2 }=0.320\end{array}$} & \multicolumn{2}{|c|}{$\begin{array}{l}\operatorname{chi} 2(37)=42.56 \\
\text { Prob }>\text { chi2 }=0.164\end{array}$} \\
\hline $\mathrm{Z1}$ & $F(2.84)=7.91^{\star}$ & & $F(2.84)=6.13^{*}$ & & $F(2.84)$ & \\
\hline $\mathrm{z2}$ & $\mathrm{F}(7.84)=2.50^{\star \star}$ & & $F(7.84)=5.05^{\star}$ & & $F(7.84)$ & \\
\hline$z 3$ & $F(5.84)=0.20$ & & $F(6.84)=0.67$ & & $F(6.84)$ & \\
\hline
\end{tabular}

Table 4 confirms that the level of disclosure reduces when the GHG emissions' performance increases, whether with regard to EAs or GHG emissions. Model 2 also suggests that it is larger entities that, all things being equal, reduce the level of transparency in the financial reporting of their EAs under IFRS.

Table 4. Results for the level of disclosure in IFRS

\begin{tabular}{|c|c|c|c|c|c|c|}
\hline & \multicolumn{2}{|l|}{ (1) ID.IFRS } & \multicolumn{2}{|c|}{ (2) ID.IFRS.EA } & \multicolumn{2}{|c|}{ (3) ID.IFRS.eGHG } \\
\hline & Coef. & Std. Err. & Coef. & Std. Err. & Coef. & Std. Err. \\
\hline DepVart-1 & 0.1936 & 0.1665 & $0.5889^{*}$ & 0.1786 & 0.3339 & 0.2158 \\
\hline GHGeP & $-0.4338^{\star \star \star}$ & 0.2465 & $-0.2074^{\star}$ & 0.0761 & $-0.1346^{\star * *}$ & 0.0756 \\
\hline Size & -0.0929 & 0.5329 & $0.3217^{\star \star \star}$ & 0.1836 & -0.3111 & 0.2026 \\
\hline ROA & 0.1217 & 0.3077 & 0.0489 & 0.0644 & 0.0414 & 0.0638 \\
\hline ROE & 0.0761 & 0.2393 & 0.0342 & 0.0860 & 0.0646 & 0.0772 \\
\hline ROS & -0.0952 & 0.4520 & -0.0200 & 0.0769 & -0.0637 & 0.0867 \\
\hline DebtE & 0.5209 & 0.4289 & 0.0519 & 0.1625 & 0.1216 & 0.1510 \\
\hline DebtA & $-0.5422^{\star \star \star}$ & 0.3069 & -0.0220 & 0.1785 & -0.0799 & 0.1611 \\
\hline Audit & -0.8406 & 1.1412 & 0.2052 & 0.2230 & -0.4594 & 0.6386 \\
\hline _cons & - & & $1.5732^{\star \star \star}$ & 0.8551 & -- & \\
\hline i.Year & Yes(1) & & Yes(1) & & Yes & \\
\hline $\begin{array}{l}\mathrm{N} \text { obs / N } \\
\text { groups }\end{array}$ & $296 / 55$ & & $296 / 55$ & & $296 / 55$ & \\
\hline $\mathrm{N}$ instr. & 52 & & 36 & & 36 & \\
\hline F statistic & $34.16^{*}$ & & $3.26^{\star}$ & & $21.36^{*}$ & \\
\hline
\end{tabular}


Table 4. Results for the level of disclosure in IFRS

\begin{tabular}{|c|c|c|c|c|c|c|}
\hline & \multicolumn{2}{|l|}{ (1) ID.IFRS } & \multicolumn{2}{|l|}{ (2) ID.IFRS.EA } & \multicolumn{2}{|c|}{ (૩) ID.IFRS.eGHG } \\
\hline & Coef. & Std. Err. & Coef. & Std. Err. & Coef. & Std. Err. \\
\hline m1 & 0.076 & & 0.022 & & 0.082 & \\
\hline m2 & 0.476 & & 0.270 & & 0.100 & \\
\hline $\begin{array}{l}\text { Hansen J } \\
\text { statistic }\end{array}$ & \multicolumn{2}{|l|}{$\begin{array}{l}\operatorname{chi} 2(35)=29.42 \\
\text { Prob }>\text { chi2 }=0.734\end{array}$} & \multicolumn{2}{|c|}{$\begin{array}{l}\operatorname{chi} 2(19)=13.67 \\
\text { Prob }>\text { chi2 }=0.803\end{array}$} & \multicolumn{2}{|c|}{$\begin{array}{l}\text { chi2 }(19)=17.62 \\
\text { Prob>chi2 }=0.548\end{array}$} \\
\hline $\mathrm{Z1}$ & $F(2.54)=3.25^{\star \star}$ & & $\begin{array}{l}F(2.54)= \\
10.50^{*}\end{array}$ & & $\begin{array}{l}\mathrm{F}(2.54)= \\
4 \cdot 50^{\star *}\end{array}$ & \\
\hline $\mathrm{z2}$ & $F(7.54)=0.71$ & & $F(7.54)=0.90$ & & $F(7.54)=0.73$ & \\
\hline$z 3$ & $F(6.54)=1.322$ & & $F(6.54)=0.99$ & & $\begin{array}{l}F(6.54)= \\
2.96^{\star \star}\end{array}$ & \\
\hline
\end{tabular}

Table 5 suggests that there is no statistically significant influence of the GHG emissions' performance on the levels of transparency in financial reporting when these are based on mandatory accounting standards. A relationship was found between ROA and ROE and the national accounting-based levels of transparency of GHG emissions. The levels of transparency in national GAAPs are also positively influenced by the presence of an external auditor's report.

Table 5. Results for the level of disclosure in national GAAPs

\begin{tabular}{|c|c|c|c|c|c|c|}
\hline & \multicolumn{2}{|c|}{ (1) ID.NGAAP } & \multicolumn{2}{|c|}{ (2) ID.NatGAAP.EA } & \multicolumn{2}{|c|}{ (3)ID.NGAAP.eGHG } \\
\hline & Coef. & Std. Err. & Coef. & Std. Err. & Coef. & Std. Err. \\
\hline DepVar t-1 & $0.5888^{\star}$ & 0.1989 & $0.7207^{\star}$ & 0.1826 & $0.7700^{\star}$ & 0.1844 \\
\hline GHGeP & -0.0725 & 0.2865 & 0.0168 & 0.1221 & -0.0688 & 0.1158 \\
\hline Size & 0.3506 & 0.5868 & 0.1278 & 0.2745 & 0.1454 & 0.1531 \\
\hline ROA & $0.3478^{\star \star *}$ & 0.1779 & 0.0919 & 0.2243 & $0.3647^{\star \star}$ & 0.1338 \\
\hline ROE & $-0.4269^{\star \star \star}$ & 0.2170 & -0.0382 & 0.2037 & $-0.4509^{\star}$ & 0.1356 \\
\hline ROS & 0.1300 & 0.4087 & 0.1332 & 0.2627 & -0.0772 & 0.1424 \\
\hline DebtE & 0.5801 & 0.7682 & 0.2963 & 0.5342 & 0.3178 & 0.2405 \\
\hline DebtA & -0.3738 & 0.8781 & -0.3692 & 0.5503 & -0.1754 & 0.2916 \\
\hline Audit & $3.2818^{\star}$ & 1.0177 & $1.3729^{\star \star \star}$ & 0.7905 & $1.1530^{*}$ & 0.4060 \\
\hline _cons & -0.8177 & 1.3353 & -- & & -0.0321 & 0.9500 \\
\hline i.Year & Yes(1) & & Yes(1) & & Yes(1) & \\
\hline $\begin{array}{l}\text { Nobs/N } \\
\text { groups }\end{array}$ & $157 / 30$ & & $157 / 30$ & & $157 / 30$ & \\
\hline $\mathrm{N}$ instruments & 27 & & 27 & & 27 & \\
\hline F statistic & $63.54^{*}$ & & $132.39^{\star}$ & & $63.01^{\star}$ & \\
\hline
\end{tabular}




\begin{tabular}{|c|c|c|c|c|c|c|}
\hline & \multicolumn{2}{|l|}{ (1) ID.NGAAP } & \multicolumn{2}{|c|}{ (2) ID.NatGAAP.EA } & \multicolumn{2}{|c|}{ (3)ID.NGAAP.eGHG } \\
\hline & Coef. & Std. Err. & Coef. & Std. Err. & Coef. & Std. Err. \\
\hline $\mathrm{m}_{1}$ & 0.043 & & 0.106 & & 0.029 & \\
\hline m2 & 0.187 & & 0.425 & & 0.859 & \\
\hline $\begin{array}{l}\text { Hansen J } \\
\text { statistic }\end{array}$ & \multicolumn{2}{|c|}{$\begin{array}{l}\operatorname{chi} 2(11)=14.68 \\
\text { Prob }>\text { chi2 }=0.197\end{array}$} & \multicolumn{2}{|c|}{$\begin{array}{l}\operatorname{chi} 2(10)=15.39 \\
\text { Prob }>\text { chi } 2=0.118\end{array}$} & \multicolumn{2}{|c|}{$\begin{array}{l}\operatorname{chi} 2(11)=11.74 \\
\text { Prob }>\text { chi2 }=0.384\end{array}$} \\
\hline $\mathrm{Z1}$ & $\begin{array}{l}\mathrm{F}(2.29)= \\
4 \cdot 60^{\star \star}\end{array}$ & & $F(2.29)$ & & $\begin{array}{l}F(2.29 \\
14.83^{*}\end{array}$ & \\
\hline $\mathrm{zz}$ & $F(7.29)=7.49^{*}$ & & $F(7.29)$ & & $F(7.29)$ & \\
\hline $\mathrm{z3}$ & $F(5.29)=0.80$ & & $F(6.29)$ & & $F(5.29)$ & \\
\hline
\end{tabular}

By using a model that controls for endogeneity and considers a weight matrix that is heteroscedastic, the relational level between transparency and the GHG emissions' performance is verified mainly for the transparency of GHG emission policies. We also concluded that an increased eco-efficiency measure of GHG emissions reduces the levels of transparency in IFRS, i.e., an accounting regulation that does not have a specific accounting treatment, but is recognized as being of high quality (Barth \& Schipper, 2008).

Evidence also showed that the level of transparency related to EAs increases in the presence of a lower eco-efficiency. This is evidence that in cases in which GHG emissions are more intense, the completeness of financial reporting is improved by providing 'good news'. Hence, as Luo et al. (2012) and Gallego-Álvarez et al. (2016) argued, by using accounting companies can present a more positive light with regard to their GHG emission practices, especially in countries where companies are subjected to market trading. The relationship between the GHG emissions' performance and the levels of transparency in financial reporting, however, should be more visible, since the purpose of a market instrument is precisely to force companies to include the 'cost of polluting' in their financial reports, and to allocate a value to it (Ascui \& Lovell, 2012). The lack of regulations from the IASB seems to be allowing company financial reporting to manage the impression of the performance of their GHG emissions, by reporting more EA policies when GHG emissions are more intense.

On the other hand, accounting regulation has been a factor that is often mentioned as leading to an increase in disclosure and is a guarantee of the information needed by stakeholders (Giner-Inchausti, 1997, 2014). We were unable to provide empirical evidence for this because national GAAPs do not distinguish the role of GHG e missions' performance in transparency levels. Veith et al. (2009) also argued about the decision-usefulness of gross approaches, which are the nature of prescribed national financial reporting.

The transparency of the GHG emissions' performance questions the financial disclosure that reflects the economic substance of the transactions and provides some comparability, as better performances reduce IFRSbased disclosure. However, because of the reduced coefficient we agree with Freedman and Jaggi (2011) that the results do not realistically reflect the amount of GHG emissions, which should affect the levels of transparency in financial reporting. Greater GHG emissions should lead to an increase in general financial transparency, which we also did not asses $\mathrm{s}$. As such, clearer guidance is needed to empower stakeholders with more visible information on exposure to EU ETS. 


\section{CONCLUSIONS}

This study aims to provide evidence of the influence of the performance of GHG emissions on the level of transparency in financial reporting. There are few such studies, because data on the subject are difficult to obtain and relate. This is true for both financial data, since the accounting treatment of EAs and GHG emissions requires an analysis of qualitative financial information, and the quantitative data in the GHG emissions figures that are self-reported. This is a critical question as it is fundamental for analyzing the financial reporting response of all polluters, and not just high pollution emitters, because market mechanisms are specifically for the purpose of making pollution effects observable; transparency in financial reporting may be the solution to this. This research highlighted the focus on transparency in financial reporting that should include the underlying economics of EU ETS transactions and, therefore, reflect the eco-efficient measurement of the performance of GHG emissions. The findings support the fact that the performance of GHG emissions is negatively related to the levels of transparency in IFRS-based financial reporting. We were also able to verify that IFRS companies, with no specific principles to apply to these matters, choose to disclose 'good news' related to EAs when their GHG emissions' performance reduces. We also suggest that the levels of transparency in financial reporting are differently influenced by the GHG emissions' performance when the presentation basis of financial statements incorporates a specific accounting treatment. It was not possible, however, to provide empirical evidence for this, which raises doubts as to whether the gross approach adopted by national regulators is internalizing GHG emission costs as the EU ETS intended. As a result,, this line of study will need to be continued in the future.

A note of caution is needed because of the inherent limitations of the study. The use of content analysis may result in bias, since it is sometimes necessary to make subjective judgements, which was true when assessing the levels of transparency and for cross-referencing the verified emissions' file with the reporting entity. We also acknowledge that the use of all the companies listed in the NPA with available annual financial statements may potentially include information that is lacking in materiality, which increases the adoption of non-disclosure and non-recognition policies.

Despite the above limitations, the GHG emissions' performance and regulatory requirements seem to be the only way of achieving more transparent financial reporting and improving pollution disclosure. This highlights the discrepancies between applying a standard with specific principles for EU ETS transactions, which is of interest to those responsible for preparing financial reports, such as regulators, managers and accountants. It is also of interest to those that have an interest in the completeness of financial reporting, which underlies the importance of the economics of the transactions.

\section{REFERENCES}

Abrell, J., Ndoye, A., Zachmann, G. (2011). Assessing the impact of the EU ETS using firm level data. Bruegel Working Paper, No. 2011/08, Bruegel, Brussels. Retrieved from https://www. econstor.eu/bitstream/10419/77988/1/664523234.pdf

Adams, C. A., Coutts, A., \& Harte, G. (1995). Corporate equal opportunities (non-) disclosure. British Accounting Review, 27(June,), 87-108. doi: 10.1006/bare.1994.0005
Al-Tuwaijri, S. A., Christensen, T. E., \& Hughes, K. E. (2004). The relations among environmental disclosure, environmental performance, and economic performance: A simultaneous equations approach. Accounting, Organizations and Society, 29(5-6), 447-471. doi: 10.1016/S0361-3682(03)00032-1

Arellano, M., \& Bond, S. (1991). Some tests of specification for panel data: Monte Carlo evidence and an application to employment equations. The Review of Economic Studies, 58(2), 277. doi: $10.2307 / 2297968$ 
Arellano, M., \& Bover, O. (1995). Another look at the instrumental variable estimation of error-components models. Journal of Econometrics, 68(1), 29-51. doi: 10.1016/03044076(94)01642-D

Ascui, F., \& Lovell, H. (2012, November). Carbon accounting and the construction of competence. Journal of Cleaner Production, 36, 48-59. doi: 10.1016/j.jclepro.2011.12.015

Ayaz, H. (2017). Analysis of carbon emission accounting practices of leading carbon emitting European Union companies. Athens Journal of Business \& Economics, 3(4), 463-486. doi: 10.30958/ajbe.3.4.5

Barth, M. E., \& Schipper, K. (2008). Financial reporting transparency. Journal of Accounting, Auditing \& Finan, 23(2), 173-19o. doi: 10.1177/0148558X0802300203

Bebbington, J., \& Larrinaga-González, C. (2008). Carbon trading: Accounting and reporting issues. European Accounting Review, 17(4), 697-717. doi: 10.1080/09638180802489162

Black, C. M. (2013). Accounting for carbon emission allowances in the European Union: In search of consistency. Accounting in Europe, 10(2), 223-239. doi: 10.1080/17449480.2013.834730

Burritt, R. L., Schaltegger, S., \& Zvezdov, D. (2011). Carbon management accounting: Explaining practice in leading German companies. Australian Accounting Review, 21(1), 8098. doi: 10.1111/j.1835-2561.2010.00121.x

Busch, T., \& Hoffmann, V. H. (2011). How hot is your bottom line? Linking carbon and financial performance. Business \& Society, 50(2), 233-265. doi: 10.1177/0007650311398780

Cho, C. H., \& Patten, D. M. (2007). The role of environmental disclosures as tools of legitimacy: A research note. Accounting, Organizations and Society, 32(7-8), 639-647. doi: 10.1016/j. aos.2006.09.009

Clarkson, P. M., Li, Y., Pinnuck, M., \& Richardson, G. D. (2015). The valuation relevance of greenhouse gas emissions under the European Union carbon emissions trading scheme. European Accounting Review, 24(3), 551-580. doi: 10.1080/09638180.2014.927782

Clarkson, P. M., Li, Y., Richardson, G. D., \& Vasvari, F. P. (2008). Revisiting the relation between environmental performance and environmental disclosure: An empirical analysis. Accounting, Organizations and Society, 33(4-5), 303-327. doi:10.1016/j.aos.2007.05.003

Connors, E., \& Gao, L. S. (2011). Corporate environmental performance, disclosure and leverage: An integrated approach. International Review of Accounting, Banking and Finance, 3(3), 1-32. Retrieved from https://corporate-sustainability.org/ wp-content/uploads/Connors-Gao.pdf.
Criado-Jiménez, I., Fernández-Chulián, M., Husillos-Carqués, F. J. \& Larrinaga-González, C. (2008). Compliance with mandatory environmental reporting in financial statements: The case of Spain (2001-2003). Journal of Business Ethics, 79(3), 245-262. doi:10.1007/s10551-007-9375-7

Cuesta, C. F., Moneva, J. M., \& Larrinaga, C. (2006). Derechos de emisión de gases efecto invernadero: Registro, valoración e información. Partida Doble, (182), 88-97. Retrieved from http://www.cambioclimatico.gov.co/jsp/loader.jsf?IServicio=Publicaciones\&lTipo=publicaciones\&lFuncion=loadContenidoPublicacion\&id=1305

Dechow, P., Ge, W., \& Schrand, C. (2010). Understanding earnings quality: A review of the proxies, their determinants and their consequences. Journal of Accounting and Economics, 5o(2-3), 344-401. doi:10.1016/j.jacceco.2010.09.001

Ehrenfeld, J. R. (2005). Eco-efficiency: Philosophy, theory, and tools. Journal of Industrial Ecology, 9(4), 6-8. doi:10.1162/108819805775248070

Elfrink, J., \& Ellison, M. (2009). Accounting for emission allowances: An issue in need of standards. The CPA Journal, 79(2), 30. Retrieved from http://proquest. umi.com/pqdweb?did=1644702761\&Fmt=7\&clien $\mathrm{tld}=20901 \& \mathrm{RQT}=309 \& \mathrm{VName}=\mathrm{PQD}$

Elo, S. \& Kyngas, H. (2008). The qualitative content analysis process. Journal of Advanced Nursing, 62(1), 107-115. doi: 10.1111/j.1365-2648.2007.04569.x

Ertimur, Y., Francis, J., Gonzales, A., \& Schipper, K. (2017). Financial reporting for pollution reduction programs. Retrieved from https://ssrn.com/abstract=2969339

European Financial Reporting Advisory Group. (2012). Emissions trading schemes: Draft comment paper. Retrieved from https://www.efrag.org/Activities/264/EFRAG-Emission-Trading-Schemes

European Financial Reporting Advisory Group. (2013). Emission trading schemes: Feedback statement on comment paper. Retrieved from https://www.efrag.org/Activities/264/EFRAG. Emission-Trading-Schemes

Freedman, M., \& Jaggi, B. (2011). Global warming disclosures: Impact of Kyoto protocol across countries. Journal of International Financial Management and Accounting, 22(1), 46-90. doi:10.1111/j.1467-646X.2010.01045.x

Gallego-Álvarez, I., Martínez-Ferrero, J., \& Cuadrado-Ballesteros, B. (2016). Accounting treatment for carbon emission rights. Systems, 4(1), 12. doi: 10.3390/systems4010012

Giner-Inchausti, B. (1997). The influence of company characteristics and accounting regulation on information disclosed by Spanish firms. European Accounting Review, 6(1), 45-68. doi:10.1080/096381897336863

Giner-Inchausti, B. (2007). La contabilidad de los derechos de emisión: Una perspectiva internacional. Revista Espanola de Financiacion y Contabilidad, 36(133), 175-193. doi: 10.1080/02102412.2007.10779619 
Giner-Inchausti, B. (2014). Accounting for emission trad ing schemes: A still open debate. Social and Environmental Accountability Journal, 34(1), 45-51. doi: 10.1080/0969160X.2014.885670

Haupt, M. \& Ismer, R. (2013). The EU Emissions Trading System under IFRS - Towards a 'True and Fair View'. Accounting in Europe, 10(1), 71-97. doi: 10.1080/17449480.2013.772726

Jaggi, B., Allini, A., Macchioni, R., \& Zagaria, C. (2018). The factors motivating voluntary disclosure of carbon information: Evidence based on Italian listed companies. Organization \& Environment, 31(2), 178-202. doi:10.1177/1086026617705282

Labra, R., \& Torrecillas, C. (2014). Guia CERO datos de panel: Un enfoque práctico. UAM-Accenture Working Papers (\#2014/16). Retrieved from https://www.catedrauam-innova.com/documents/Working\%2opapers/WP2014_16_Guia\%20CERO\%20 para\%20datos\%20de\%2opanel_Un\%2oenfoque\%2opractico.pdf

Larrinaga, C., Carrasco, F., Correa, C., Llena, F., \& Moneva, J. (2002). Accountability and accounting regulation: The case of the Spanish environmental disclosure standard. European Accounting Review, 11(4), 723-740. doi:10.1080/0963818022000001000

Leung, D. Y. \& Chung, B.P.M. (2019). Content analysis: Using critical realism to extend Its utility. In P. Liamputtong (Ed.), Handbook of research methods in health social sciences (pp. 827-841). Singapore: Springer. doi: 10.1007/978-981-10-52514_102

Liu, Y., Zhou, X., Yang, J. \& Hoepner, A. G. F. (2017). Corporate Carbon Emissions and Financial Performance: Does Carbon Disclosure Mediate the Relationship in the UK? SSRN Electronic Journal. doi:10.2139/ssrn.2941123

Llena, F., Moneva, J. M., \& Hernandez, B. (2007, January). Environmental disclosures and compulsory accounting standards: The case of Spanish annual reports. Business Strategy and the Environment, 16, 50-63. doi:10.1002/bse.466

Lovell, H., Sales de Aguiar, T., Bebbington, J., \& Larrinaga-Gonzalez, C. (2010). Accounting for Carbon. Research Report 122 - ACCA. London (UK): The Association of Chartered Certified Accountants. Retrieved from: https://www.accaglobal.com/ content/dam/acca/global/PDF-technical/climate-change/rr122-001.pdf

Lovell, H., Bebbington, J., Larrinaga, C., \& Sales de Aguiar, T. (2013). Putting carbon markets into practice: A case study of financial accounting in Europe. Environment and Planning C: Government and Policy, 31(4), 741-757. doi: 10.1068/c1275

Luo, L., Lan, Y. C., \& Tang, Q. (2012). Corporate incentives to disclose carbon information: Evidence from the CDP Global 500 Report. Journal of International Financial Management and Accounting, 23(2), 93-120. doi: 10.1111/j.1467646X.2012.01055.X
MacKenzie, D. (2009). Making things the same: Gasses, emission rights and the politics of carbon markets. Accounting, Organizations and Society, 34(3-4), 440-455. doi: 10.1016/j. aos.2008.02.004

Mateos, A. I., \& Bilbao, I. (2007). Planificación contable y derechos de emission de gases efecto invernadero. Revista Universo Contábil, 3(3), 101-122. Retrieved from http://www.redalyc. org/service/redalyc/downloadPdf/1170/117016548008/1

Matsumura, E. M., Prakash, R., \& Vera-Muñoz, S. C. (2014). Firm-value effects of carbon emissions and carbon disclosures. Accounting Review, 89(2), 695-724. doi: 10.2308/accr50629

Milanés-Montero, P., \& Pérez-Calderón, E. (2011). Corporate environmental disclosure and legitimacy theory: An Europe perspective. Environmental Engineering and Management Journal, 10(12), 1883-1891. doi:10.30638/eemj.2011.252

Ortas, E., Gallego-Álvarez, I., \& Álvarez-Etxeberria, I. (2015). Financial factors influencing the quality of corporate social responsibility and environmental management disclosure: A quantile regression approach. Corporate Social Responsibility and Environmental Management, 22(6), 362-380. doi:10.1002/csr.1351

Patten, D. M. (2002). The relation between environmental performance and environmental disclosure: A research note. Accounting, Organizations and Society, 27, 763-773. doi: 10.1016/S0361-3682(02)00028-4

Pindado, J., \& Requejo, I. (2015). Panel data: A methodology for model specification and testing. (3rd ed.) C. Cooper, K. Paudy al (Eds.), Wiley encyclopedia of management, Chapter 4, John Wiley \& Sons. doi: 10.1002/9781118785317.weomo40013

Prado-Lorenzo, J.-M., Rodríguez-Domínguez, L., Gallego-Álvarez, I., \& García-Sánchez, I.-M. (2009). Factors influencing the disclosure of greenhouse gas emissions in companies world-wide. Management Decision, 47(7), 1133-1157. doi: $10.1108 / 00251740910978340$

PricewaterhouseCoopers \& International Emissions Trading Association (2007). Trouble-Entry accounting -Revisited. Uncertainty in accounting for the EU Emissions Trading Scheme and Certified Emission Reductions. London: PricewaterhouseCoopers. Retrieved from http://www.ieta.org/index. php?option $=$ com_content $\&$ view $=$ article $\& i d=329 \% 3$ Atrou ble-entry-accounting---revisited ${ }^{*} \&$ catid $=27 \% 3$ Aarchived-reports\&ltemid $=93$

Qian, W., \& Schaltegger, S. (2017). Revisiting carbon disclosure and performance: Legitimacy and management views. British Accounting Review, 49(4), 365-379. doi:10.1016/j. bar.2017.05.005

Qiu, Y., Shaukat, A., \& Tharyan, R. (2016). Environmental and social disclosures: Link with corporate financial performance. British Accounting Review, 48(1), 102-116. doi:10.1016/j. bar.2014.10.007 
Ragan, J. M., \& Stagliano, A. J. (2007). Cap and trade allowance accounting: A divergence between theory and practice. Journal of Business \& Economics Research, 5(11), 47-58. doi: 10.19030/jber.v5i11.2602

Roberts, R. W. (1992). Determinants of corporate social responsibility disclosure: An application of stakeholder theory. Accounting, Organizations and Society, 17(6), 595-612. doi: 10.1016/0361-3682(92)90015-K

Schiemann, F., \& Sakhel, A. (2019). Carbon disclosure, contextual factors, and information asymmetry: The case of physical risk reporting. European Accounting Review, 28(4), 791-818. doi: $10.1080 / 09638180.2018 .1534600$

Steenkamp, N., Rahman, A., \& Kashyap, V. (2011, 5-7 Decembe). Recognition, measurement and disclosure of carbon emission allowances under the EU ETS: An exploratory study. Paper presented at the CSEAR 2011 Australasian Conference, University of Tasmania, Australia. Retrieved from http://www.massey.edu/massey/ $\mathrm{fms} /$ Colleges/College\%20of\%20Business/School\%20of\%20 Accountancy/ARA\%202012/Kashyap_Accounting\%2ofor.pdf
Veith, S., Zimmermann, J., \& Werner, J. R. (2009). Competing accounting treatments for emission rights: A capital market perspective, Available at SSRN 1323810.605-613. Retrieved from https://papers.ssrn.com/sol3/papers.cfm?abstract_ id $=1323810$

Warwick, P., \& Ng, C. (2012). The "cost" of climate change: How carbon emissions allowances are accounted for amongst European Union companies. Australian Accounting Review, 22(1), 54-67. doi: 10.1111/j.1835-2561.2011.00158.x

Windmeijer, F. (2005). A finite sample correction for the variance of linear efficient two-step GMM estimators. Journal of Econometrics, 126(1), 25-51. doi: 10.1016/j.jeconom.2004.02.005

Yu, H. (2013). The EU ETS and firm profits: An ex-post analysis of Swedish energy firms. Environmental Economics, 4(3), 5971. Retrieved from https://www.businessperspectives.org/ images/pdf/applications/publishing/templates/article/assets/5426/ee_2013_03_Yu.pdf

\section{AUTHORS' CONTRIBUTIONS}

Patricia Milanés-Montero, Esteban Pérez-Calderón and Ana Isabel Dias worked on the conceptualization and theoretical-methodological approach. The theoretical review was conducted by Esteban Pérez-Calderón, and Patricia Milanés-Montero. Data collection was coordinated by Ana Isabel Dias. Data analysis included Ana Isabel Dias, Esteban Pérez-Calderón, and Patricia Milanés-Montero. Patricia Milanés-Montero, Esteban PérezCalderón, and Ana Isabel Dias worked together in the writing and final revision of the manuscript. 